\title{
Increased Knowledge About COVID-19 Vaccination of Non- Medical College Students in Surabaya
}

\author{
Alma Rossabela Setyanisa ${ }^{a}$, Dinda Dwi Purwatia , M. Masrur Rizala , Danti Nur \\ Indiastuti $^{b^{*}}$ \\ Corresponding author: danti-n-i@fk.unair.ac.id* \\ ${ }^{a}$ Medical Program, Faculty of Medicine, Universitas Airlangga, Surabaya, 60131, Indonesia \\ ${ }^{\mathrm{b}}$ Department of Anatomy, Histology, and Pharmacology, Division of Pharmacology, Faculty of Medicine, Universitas Airlangga, \\ Surabaya, 60131, Indonesia
}

\begin{abstract}
Introduction: The increasing number of COVID-19 cases in Indonesia that occur every day makes the government continue to promote the COVID-19 vaccination program as a form of preventing the transmission of the COVID-19 virus. But, the coverage of COVID-19 vaccination in Indonesia is still relatively low, where on July 15,2021 , dose 1 was $19.82 \%$ and dose 2 was $7.79 \%$. The majority of people who are worried about the safety and effectiveness of vaccines express distrust of vaccines and question the halalness of vaccines. This illustrates the lack of knowledge about COVID-19 vaccination. The aim of this study is to increase the knowledge of non-medical college students in Surabaya about COVID-19 vaccination, so that they can be able to provide vaccination education to their environment, increase public enthusiasm to participate in the vaccination program, and have an impact on accelerating the vaccination program in Indonesia.

Method: The measurement of the level of knowledge was conducted in Surabaya at the COVID-19 vaccination education socialization online event with the sample of non-medical college students in Surabaya. The measurement instrument used is through pre-test and post-test questions which were filled out through an online form by the sample before and after receiving educational socialization. Sample selection method with total sampling with the results obtained 92 samples. All data were processed using a statistical analysis program with the Wilcoxon Signed Rank Test with a significant value at $\mathrm{p}<0.05$.

Results: The results obtained are an increase in the average value between the pre-test and post-test (65.21; 77.85). There is a significant difference in knowledge of COVID-19 vaccination between the pre-test and post-test with a value of $\mathrm{p}<0.001(\mathrm{p}<0.05)$.

Conclusion: Based on data from online educational socialization events that have been held, there is an increased knowledge and a significant difference in knowledge of the COVID-19 vaccine in 92 non-medical college students in Surabaya as indicated by the results of the evaluation scores between the pre-test and posttest.
\end{abstract}

Keywords: Knowledge; COVID-19; Vaccine; Non-Medical; College Students

\section{Introduction}

The ongoing Corona Virus Disease 2019 (COVID-19) pandemic caused by severe acute respiratory syndrome coronavirus 2 (SARS-CoV-2) has caused high morbidity and mortality worldwide [1]. While physical distancing, quarantine and isolation have been effective in limiting the number of people infected 
during the pandemic in the short term, they have not created immunity in the population. The lack of an effective treatment for COVID-19 makes rapid action in the development of a potential vaccine against COVID-19 so as to realize immunity in the population [2]. There are several types of COVID-19 vaccines that already exist and are being developed, namely Protein Sub-unit vaccines, Viral Vectored vaccines, mRNA vaccines, and DNA vaccines [3]. A study shows that it is better to get a COVID-19 vaccine that is already available than a vaccine that is available at a later date even if the latter vaccine has much higher efficacy. This is because as the pandemic progresses and the number of cases increases every day, the potential benefits of a higher efficacy vaccine are offset by an increase in additional cases, hospitalizations, and associated costs. This is the case for vaccines that prevent infection and that reduce disease severity [4]. Therefore, the current COVID-19 vaccination is very important.

Indonesia makes the implementation of the COVID-19 vaccination with the aim of protecting the public from SARS-CoV-2 infection which can cause illness and death as part of the strategy for dealing with the COVID-19 pandemic. If vaccination coverage is high and evenly distributed, meaning that enough people in the community are vaccinated, it is hoped that group immunity will be formed which can reduce the spread of the virus, break the chain of transmission, and in turn will stop the outbreak [5]. However, the coverage of COVID-19 vaccination in Indonesia is still relatively low where on July 15, 2021 dose 1 was $19.82 \%$ and dose 2 was $7.79 \%$ is still very far from getting group immunity [6]. The Surabaya Health Office reported that on June 18, 2021, the cumulative number of vaccine recipients reached 1,289,265 consisting of health workers, public services, the elderly, vulnerable communities, and the general public [7].

A survey conducted by the Ministry of Health and the Indonesian Technical Advisory Group on Immunization (ITAGI) revealed that the majority of people are worried about the safety and effectiveness of vaccines, express distrust of vaccines, and question the halalness of vaccines. Around $65 \%$ of respondents said they were willing to accept the COVID-19 vaccine if provided by the government, $8 \%$ of them refused, and the remaining $27 \%$ expressed doubts about the government's plan to distribute the COVID-19 vaccine [8]. Research shows that specific beliefs and attitudes toward COVID-19 vaccination are closely related to intention to vaccinate [9]. Doubts arise from some people who are afraid of needles and who have experienced side effects after administering the vaccine. This is also added by many people who do not believe that COVID-19 is real and can threaten public health. Some people claim that the pandemic is a product of propaganda, conspiracy, hoax, and/or a deliberate attempt to spread fear through the media for profit [8].

The government has a plan to accelerate the implementation of COVID-19 vaccination with a vaccination target of 1 million doses per day through the provision of vaccines and logistics for COVID-19 vaccinations that meet quality, efficacy and safety requirements [10]. All parties need to synergize and collaborate to be able to accelerate the national vaccination program so that group immunity can be achieved immediately [10]. Students as agents of change are one of the components that can help make the COVID-19 vaccination program a success. Departing from the existing problems, the purpose of this study is to increase Surabaya students' knowledge of COVID-19 vaccination so that they are able to provide education about vaccination to their environment, increase public enthusiasm for participating in the vaccination program, and ultimately have an impact on accelerating the vaccination program in Indonesia.

\section{Method}

Knowledge measurement was carried out on the same day through an education socialization online event on July 17th, 2021 in Surabaya. The sample criteria were non-medical college students in Surabaya who took part in the COVID-19 vaccination education event from beginning to end and were willing to fill out pre-test and post-test questions. Education participants worked on pre-test questions at the beginning of the activity 
and continued with educational materials provided by the presenters regarding the development and importance of COVID-19 vaccination for 60 minutes. After that, a question and answer session was held for 20 minutes and ended with filling out the post-test questions.

The total sample in this study was 92 samples using the total sampling method. The instruments used are pre-test and post-test questions which were filled out through an online form by the samples. The pre-test and post-test consist of 8 questions regarding information about the COVID-19 vaccination which have been tested for validity and reliability. All data were processed using a statistical analysis program with the Wilcoxon Signed Rank Test with a p-value $<0.05$, considered statistically significant difference between before and after the intervention.

\section{Results}

Table 1. Distributions of Pre-Test and Post-Test Scores

\begin{tabular}{|c|c|c|c|c|}
\hline \multirow{2}{*}{ Category } & \multicolumn{2}{|c|}{ Pre-Test } & \multicolumn{2}{|c|}{ Post-Test } \\
\hline & $\mathrm{f}$ & $\%$ & $\mathrm{f}$ & $\%$ \\
\hline Score $0-30$ & 5 & 5.4 & 0 & 0 \\
\hline Score $31-70$ & 46 & 50 & 24 & 26.1 \\
\hline Score 71-100 & 41 & 45.6 & 68 & 73.9 \\
\hline Total & 92 & 100 & 92 & 100 \\
\hline
\end{tabular}

The score in the pre-test was dominated by a score between 31-70 (50\%) and the post-test was dominated by a score between 71-100 (73.9\%). None of the respondents scored 0-30 on the post-test results (Table 1).

Table 2. Knowledge Before and After Education Socialization of COVID-19 Vaccination (n=92)

\begin{tabular}{|c|c|c|c|}
\hline \multirow{2}{*}{ No } & \multirow{2}{*}{ Item } & \multicolumn{2}{|c|}{ Completely Correct } \\
\hline & & Pre-Test & Post-Test \\
\hline 1. & Vaccines are included in the type of immunity ... & $63 \%$ & $83.7 \%$ \\
\hline 2. & $\begin{array}{l}\text { The following condition that is not eligible for the COVID-19 } \\
\text { vaccination is ... }\end{array}$ & $66.3 \%$ & $78.3 \%$ \\
\hline 3. & $\begin{array}{l}\text { The following condition that is delayed getting the COVID-19 } \\
\text { vaccination is ... }\end{array}$ & $85.9 \%$ & $92.4 \%$ \\
\hline 4. & $\begin{array}{l}\text { Herd immunity will be achieved if the population that has } \\
\text { received the complete vaccine is at least as many as... }\end{array}$ & $46.7 \%$ & $67.4 \%$ \\
\hline 5. & $\begin{array}{l}\text { According to WHO, the fastest and strongest variant of the } \\
\text { COVID-19 virus is... }\end{array}$ & $78.3 \%$ & $90.2 \%$ \\
\hline 6. & $\begin{array}{l}\text { The true impact of the new COVID- } 19 \text { variant on the } \\
\text { COVID- } 19 \text { vaccine is... }\end{array}$ & $29.3 \%$ & $41.3 \%$ \\
\hline 7. & $\begin{array}{l}\text { When the COVID-19 virus circulates widely in the } \\
\text { community and causes many infections that occur, the } \\
\text { possibility of the COVID-19 virus mutating increases } \\
\text { because, except ... }\end{array}$ & $64.1 \%$ & $78.3 \%$ \\
\hline 8. & The recommended number of COVID-19 vaccines that are & $88 \%$ & $91.3 \%$ \\
\hline
\end{tabular}


safe and can get high amounts of antibodies are as many as ...

From each question an increase in the percentage of respondents who answered correctly. The highest increase in respondents who answered the questions correctly was in questions number 1 and 4 , each of which increased by $20.7 \%$ (Table 2 ).

Table 3. Average of Pre-Test and Post-Test Scores

\begin{tabular}{llll}
\hline & Category & Total Score & Average Score \\
\hline Pre-Test & 6000 & 65.21 \\
Post-Test & 7162.5 & 77.85 \\
\hline
\end{tabular}

The average value of the post-test increased from the pre-test which is 12.64 scores $(65.21 ; 77.85)$ (Table $3)$.

Table 4. Test Results Difference between Pre-Test and Post-Test Scores

\begin{tabular}{llcl}
\hline & \multicolumn{2}{c}{ Respondent } & P \\
\cline { 2 - 3 } Category & \multicolumn{2}{c}{ f } & 1.1 \\
\hline Post-Test Score $<$ Pre-Test Score & 1 & 34.8 & $0.000^{*}$ \\
Post-Test Score $>$ Pre-Test Score & 32 & 64.1 & \\
Post-Test Score $=$ Pre-Test Score & 59 & 100 & \\
Total & 92 & & \\
\hline
\end{tabular}

*Significant level at $\mathrm{p}<0.05$

There was only one respondent who got a post-test score that was lower than the pre-test score. The results of the different tests using the Wilcoxon Signed Rank Test showed a significant value of $\mathrm{p}<0.001$ $(<0.05)$, which means that there is a significant difference in knowledge about COVID-19 vaccination between before and after being given educational materials (Table 4).

\section{Discussion}

From the results of research conducted by Lin, Tu and Beitsch, 2021, it is clear that there are doubts about the vaccination process. Factors that cause doubt such as religion, gender, political ideology, and belief in medical and scientific institutions have been shown to be associated with vaccine indecision, both in general and in relation to the COVID-19 vaccine in particular. In addition to this, specific beliefs and attitudes towards COVID-19 vaccination are closely related to vaccination intentions [9]. In addition to this research, Indonesia also conducted a survey related to COVID-19 vaccination conducted by the Ministry of Health and the Indonesian Technical Advisory Group on Immunization (ITAGI). In the survey, the majority of people were concerned about the safety and effectiveness of vaccines, expressed distrust of vaccines, questioned the halalness of vaccines and doubted vaccinations, especially due to fear of needles and their side effects [8].

Our education is about COVID-19 vaccination, which aims to find out the level of knowledge of nonmedical students before and after attending education socialization. From the result, it was found that there was an increase in the value of knowledge about vaccines which is indicated by an increase in the distribution of participants who got a higher post-test score at a score of $71-100$, which was $28.3 \%$ (Table 1). Then, based 
on table 2 , it can be seen that there is an increase in the post-test score on each question topic and there is an increase of average score from pre-test and post-test (Table 3). From these data, it can be concluded that the educational activities carried out can increase the knowledge of non-medical students who participate in these activities. This result is also the same as the socialization activities carried out by Wardhana in 2020. In the activities carried out by him, the people who participated in the socialization were so enthusiastic that they created five alternative policy models to break the COVID-19 chain [11]. Another study also showed an increase in the level of knowledge about COVID-19 carried out in 2020 after participants received socialization [12].

Knowledge of this vaccine, based on the increase in this research that has been carried out, there are several topics that still need to be re-educated to the public, namely the topic of the new variant of COVID-19 and herd immunity. This can happen because the participants who follow are non-medical college students who still rarely hear or understand about these two things. Need to remember that the process of providing socialization must be adjusted to the targets so that increased knowledge can be achieved [13]. On the topic of the new variant of COVID-19, the pre-test and post-test scores were still less than 50\%, namely $29.3 \%$ and 41.3\% (Table 2). The Indonesian government through the COVID-19 Handling Task Force issued an Addendum to Circular Number 8 of 2021 concerning International Travel Health Protocols during the 2019 CoronaVirus Disease Pandemic that announcing an increase in the spread of the SARS-CoV-2 and another new variant [14]. The delta variant is one of the variants that is often discussed because it is considered a variant that causes a spike in cases of COVID-19 [15]. Based on data from covid19.go.id, the number of confirmed cases in Indonesia as of July 26, 2021 is 3,194,733 [16]. If with information data there is an increase in the spread of the SARS-CoV-2 virus and other new variants of SARS-CoV-2, this information is still not widely known by the Indonesian people. Coupled with studies that state the relationship between the delta variant and available vaccines only show a small difference in effectiveness, so the findings call for and urge more people to get the vaccine even though new variants of the COVID-19 virus emerge [15]. This is important to convey, because the results of previous studies state that understanding the causes, sources of transmission, and transmission will increase public awareness of the process of spreading the virus and become one of the preventive measures to slow down transmission [17].

Another topic that is still low is the topic of herd immunity. From the data we get the pretest value is $46.7 \%$ and the post-test value is $67.4 \%$ and is the second lowest pre-test and post-test value (Table 2). Based on a review of Faizal and Ariska in their article, herd immunity is a phenomenon that occurs in groups of people who are resistant to diseases such as people without a fully functioning immune system, such as people with a dysfunctional spleen, people undergoing chemotherapy, people with HIV and others [18] Threshold of herd immunity is approximately $67 \%$ from the total country's population [19]. The study said that herd immunity in Indonesia was still controversial to be applied in Indonesia because at that time a vaccine had not yet been found. But now a vaccine has been found and needs to be reviewed regarding the plan to implement herd immunity in Indonesia. The principle of creating herd immunity is that people who are not immunized will be protected by people who are vaccinated. The achievement of the person being vaccinated depends on the disease that becomes a pandemic [18]. One way that can increase public knowledge and awareness of COVID-19 is by conducting education in the form of socialization [11]. A high level of knowledge will create a high level of trust and create a positive attitude in dealing with health crisis situations that occur [20]. So it is necessary to re-educate about herd immunity to create an immediate herd immunity system.

There is a significant difference between the results of the pre-test and post-test after the test with a value of $\mathrm{p}<0.001$ (Table 4). Another study also got the same results with the conclusion that more education is needed to create a positive attitude and be ready to face crisis conditions [12]. The educational activities carried out can increase the knowledge of the participants who participated in the event. As explained in another study, it is necessary to increase awareness of information about COVID-19, one of which is shown 
to students [21] So that if the education continues to be disseminated from non-medical students to the community, the percentage of refusals and doubts decreases, the acceleration of the vaccination process can be more easily implemented, and the formation of group immunity can be achieved quickly so that the Indonesian people are ready to face this pandemic.

\section{Conclusion}

The educational socialization provided with material on COVID-19 vaccination aims to increase knowledge to non-medical college students in Surabaya as participants through presentations and question and answer sessions. With the implementation of this online socialization event, it can be concluded that there was an increase in knowledge and a significant difference in knowledge of the COVID-19 vaccine in 92 participants as indicated by the results of the evaluation scores between the pre-test and post-test. It is hoped that later educational programs will continue to be held for wider targets. So that the level of knowledge about COVID-19 vaccination in the community can increase and help the COVID-19 vaccination program to immediately reach the target of achieving herd immunity.

\section{Acknowledgements}

The authors would like to thank the authorities of the Faculty of Medicine Universitas Airlangga and other related parts for facilitating and allowing this study to be completed.

\section{References}

[1] Hamlet A, Djafaara BA, Cucunubá Z, Mesa DO, Green W, Thompson H, et al. The impact of COVID-19 and strategies for mitigation and suppression in low- and middle-income countries 2020;422:413-22.

[2] Sanche S, Lin YT, Xu C, Romero-Severson E, Hengartner N, Ke R. RESEARCH High Contagiousness and Rapid Spread of Severe Acute Respiratory Syndrome Coronavirus 2. Emerging Infectious Diseases 2020;26:1470-7. https://doi.org/10.3201/eid2607.200282.

[3] Wang N, Shang J, Jiang S, Du L. Subunit Vaccines Against Emerging Pathogenic Human Coronaviruses. Frontiers in Microbiology 2020;11. https://doi.org/10.3389/fmicb.2020.00298.

[4] Bartsch SM, Shea KJO, Wedlock PT, Strych U, Ferguson MC, Bottazzi ME, et al. The Benefits of Vaccinating With the First Available COVID-19 Coronavirus Vaccine 2020.

[5] Kementerian Kesehatan RI. FREQUENTLY ASKED QUESTION PELAKSANAAN VAKSINASI COVID 2020.

[6] Kementerian Kesehatan RI. Cakupan Vaksinasi COVID-19 Dosis 1 dan 2 di Indonesia 2021. https://vaksin.kemkes.go.id/\#/vaccines (accessed December 30, 2021).

[7] Pemerintah Kota Surabaya. Wali Kota Eri Terus Dorong Percepatan Vaksinasi Gotong Royong 2021. https://www.surabaya.go.id/id/berita/61076/wali-kota-eri-terus-dorong-perc.

[8] Indonesian Technical Advisory Group on Immunization. Survei Penerimaan Vaksin COVID-19 di Indonesia 2020.

[9] Lin C, Tu P, Beitsch LM. Confidence and receptivity for covid-19 vaccines: A rapid systematic review. Vaccines 2021;9:1-32. https://doi.org/10.3390/vaccines9010016.

[10] Kementerian Kesehatan RI. Percepatan Pelaksanaan Vaksinasi COVID19. Indonesia: 2021.

[11] Wardhana Y. Socialization Of Policy Alternative Models In Efforts Of Handle Covid-19 Pandemic Problems In Yosorejo Village, Metro City. vol. 02. 2020.

[12] Khaerunnisa S, Syafa'ah I, Wungu CDK, Prabowo GI, Handajani R, Safitri I, et al. The Improvement of 
Community Knowledge, Attitudes and Practices After Covid-19 Socialization. Folia Medica Indonesiana 2021;57:95. https://doi.org/10.20473/fmi.v57i2.26262.

[13] Ferdous MZ, Islam MS, Sikder MT, Mosaddek ASM, Zegarra-Valdivia JA, Gozal D. Knowledge, attitude, and practice regarding COVID-19 outbreak in Bangladesh: An onlinebased cross-sectional study. PLoS ONE 2020;15. https://doi.org/10.1371/journal.pone.0239254.

[14] Satuan Gugus Penanganan Covid-19. Addendum Surat Edaran nomor 8 tahun 2021 tentang Protokol Kesehatan Perjalanan Internasional pada Masa Pandemi Corona Virus Disease 2019. Indonesia: 2021.

[15]Lopez Bernal J, Andrews N, Gower C, Gallagher E, Simmons R, Thelwall S, et al. Effectiveness of Covid-19 Vaccines against the B.1.617.2 (Delta) Variant. New England Journal of Medicine 2021;385:585-94. https://doi.org/10.1056/nejmoa2108891.

[16] Satuan Gugus Penanganan Covid-19. Peta Sebaran Covid-19 2021. https://covid19.go.id/peta-sebarancovid19 (accessed June 27, 2021).

[17] Al-Hanawi MK, Angawi K, Alshareef N, Qattan AMN, Helmy HZ, Abudawood Y, et al. Knowledge, Attitude and Practice Toward COVID-19 Among the Public in the Kingdom of Saudi Arabia: A CrossSectional Study. Frontiers in Public Health 2020;8. https://doi.org/10.3389/fpubh.2020.00217.

[18] Faizal IA, Ariska Nugrahani N. Herd immunity and COVID-19 in Indonesia. Jurnal Teknologi Laboratorium 2020;9:21-8. https://doi.org/10.29238/teknolabjournal.v9i1.219.

[19] Randolph HE, Barreiro LB. Herd Immunity: Understanding COVID-19. Immunity 2020;52:737-41. https://doi.org/10.1016/j.immuni.2020.04.012.

[20] Azlan AA, Hamzah MR, Sern TJ, Ayub SH, Mohamad E. Public knowledge, attitudes and practices towards COVID-19: A cross-sectional study in Malaysia. PLoS ONE 2020;15. https://doi.org/10.1371/journal.pone.0233668.

[21] Paul A, Sikdar D, Hossain MM, Amin MR, Deeba F, Mahanta J, et al. Knowledge, attitudes, and practices toward the novel coronavirus among Bangladeshis: Implications for mitigation measures. PLoS ONE 2020;15. https://doi.org/10.1371/journal.pone.0238492. 